\title{
A multi-centre international quality control study comparing mRNA splicing assay protocols and reporting practices from the ENIGMA consortium
}

\author{
P Whiley ${ }^{1 *}$, LC Walker ${ }^{1}$, KConFab $^{3}$, M De LA Hoya ${ }^{8}$, B Wappenschmidt $^{6}$, A Becker $^{6}$, A Blanco $^{10}$, MJ Blok ${ }^{9}$, \\ MA Caligo ${ }^{16}$, C Chatfield $^{14}$, F Couch ${ }^{13}$, O Diez ${ }^{15}$, L Fachal $^{10}$, L Guidugli ${ }^{13}$, S Gutiérrez Enríquez ${ }^{15}$, T Hansen ${ }^{7}$, \\ C Houdayer $^{11}$, S Imrie ${ }^{18}$, A Lafferty ${ }^{18}$, C Lázaro ${ }^{4}$, M Menéndez ${ }^{4}$, M Montagna ${ }^{12}$, G Montalbán ${ }^{15}$, M Santamariña ${ }^{10}$,

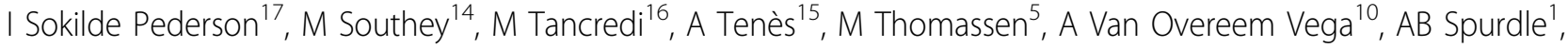 \\ MA Brown ${ }^{2}$
}

From Familial Aspects of Cancer 2011 Research and Practice: A combined meeting of kConFab, Australian Breast Cancer Family Study, Australian Colorectal Cancer Family Study, Australian Ovarian Cancer Study, Family Cancer Clinics of Australia and New Zealand and kConFab

Kingscliff, Australia. 23-26 August 2011

Classification of intronic and predicted missense changes in the breast cancer susceptibility genes $B R C A 1$ and $B R C A 2$ remains a significant challenge for management of patients carrying these variants. Defective mRNA splicing is established as a pathway to disease, and mRNA analysis of unclassified variants has been shown to assist in classification and genetic counselling. However the interpretation of splicing assay results can be difficult, particularly for those variants that give rise to aberrations in a background of naturally occurring isoforms.

The ENIGMA (Evidence-based Network for the Interpretation of Germline Mutant Alleles) consortium was set up to facilitate research and improve research methods used to classify rare variants in the $B R C A 1$ and $B R C A 2$ (and potentially other) breast cancer predisposition genes. ENIGMA has established a Splicing Working Group, with stated purpose to pool the expertise of different active research groups to conduct large-scale studies that improve the clinical classification of likely spliceogenic variants. An initial project of the Splicing Working Group is to assess the consistency of protocols and results obtained across the multiple participating laboratories from Australia, Europe, UK and the USA. A comparison of mRNA assay protocols in use across 21

${ }^{1}$ Genetic \& Population Health Division, Queensland Institute of Medical Research, Brisbane, Queensland, Australia

Full list of author information is available at the end of the article labs has identified differences in source material for RNA assays (cultured and uncultured lymphocytes, lymphoblastoid cell lines (LCLs) or constructs), differential use of nonsense-mediated decay inhibitors, and numerous differences in mRNA extraction, DNase treatment and cDNA synthesis methods. A second phase of the project is now underway to determine the impact of the splicing assay methods routinely used by these laboratories on assay data and clinical interpretation of a panel of variants. LCLs were selected from the $\mathrm{kConFab}$ repository from carriers of a variant associated with single major aberrant mRNA transcript absent in controls $(n=4)$; carriers of a variant associated with a complicated aberrant mRNA splicing profile involving multiple transcripts including naturally occurring isoforms $(n=5)$; female cancer-free controls $(\mathrm{n}=11)$. LCLs have already been distributed to 15 of 20 participating sites, and mRNA assays are underway. Preliminary results indicate that major aberrations associated with several variants mirror results previously observed for mRNA from uncultured lymphocytes. In addition, there is evidence for notable differences in expression of some isoforms compared to results previously observed for RNA from uncultured lymphocytes. This collaborative effort will provide information to inform optimal standardised mRNA splicing assay methodology, and to improve guidelines for clinical interpretation of assay results.

(c) 2012 Whiley et al; licensee BioMed Central Ltd. This is an Open Access article distributed under the terms of the Creative Commons 


\section{Author details}

'Genetic \& Population Health Division, Queensland Institute of Medical Research, Brisbane, Queensland, Australia. ${ }^{2}$ School of Chemistry and Molecular Biosciences, University of Queensland, Australia. ${ }^{3}$ Peter MacCallum Cancer Centre, St Andrews Place, East Melbourne, Victoria, Australia. ${ }^{4}$ Genetic Diagnosis Unit, Hereditary Cancer Program, Institut Català d'Oncologia, Barcelona, Spain. ${ }^{5}$ Department of Clinical Genetics, Odense University Hospital, Odense C, Denmark. ${ }^{6}$ Department of Obstetrics \& Gynecology, University Hospital Cologne, Cologne, Germany. ${ }^{7}$ Genomic Medicine,

Department of Clinical Biochemistry, Rigshospitalet, Copenhagen, Denmark. ${ }^{8}$ Laboratorio Oncología Molecular, Hospital Clínico San Carlos, Madrid, Spain. ${ }^{9}$ Department of Clinical Genetics, Maastricht University Medical Centre, Maastrict, The Netherlands. ${ }^{10}$ Fundación Pública Galega de Medicina Xenómica-SERGAS, Grupo de Medicina Xenómica-USC, CIBERER, IDIS, Santiago de Compostela, Spain. ${ }^{11 G e ́ n e ́ t i q u e ~ C o n s t i t u t i o n n e l l e, ~ I n s t i t u t ~ C u r i e, ~}$ Paris, France. ${ }^{12}$ Instituto Oncologico Veneto, U.O.C. Immunologia e Diagnostica Molecolare Oncologica, Padua, Italy. ${ }^{13}$ Department of Laboratory Medicine and Pathology, Mayo Clinic College of Medicine, Rochester, USA. ${ }^{14}$ Department of Pathology, University of Melbourne, Melbourne, Victoria, Australia. ${ }^{15}$ Oncogenetics Laboratory, Vall d'Hebron Institute of Oncology (VHIO), University Hospital Vall d'Hebron, Barcelona. Spain. ${ }^{16}$ Istituto di Anatomia Patologica, Università di Pisa, Pisa, Italy. ${ }^{17}$ Section of Molecular Diagnostics, Department of Clinical Biochemistry, Aalborg University Hospital, Aalborg, Denmark. ${ }^{18}$ West of Scotland Regional Genetics Service, Glasgow, Scotland, UK.

Published: 12 April 2012

doi:10.1186/1897-4287-10-S2-A87

Cite this article as: Whiley et al:: A multi-centre international quality control study comparing mRNA splicing assay protocols and reporting practices from the ENIGMA consortium. Hereditary Cancer in Clinical Practice 2012 10(Suppl 2):A87.

\section{Submit your next manuscript to BioMed Central and take full advantage of:}

- Convenient online submission

- Thorough peer review

- No space constraints or color figure charges

- Immediate publication on acceptance

- Inclusion in PubMed, CAS, Scopus and Google Scholar

- Research which is freely available for redistribution

Submit your manuscript at www.biomedcentral.com/submit 